\title{
THE LONDON SCHOOL OF ORIENTAL STUDIES
}

\section{A Great Opportunity for Missionary Studentg}

A GREAT and long-wished-for step forward in the encouragement of Oriental learning was taken when, in June 1916, the Royal Charter was issued for the establishment of the "School of Oriental Studies, London Institution," in Finsbury Circus, London E. C. The term "Oriental" is used in an elastic sense in the title of this new Institution, which was formally opened by His Majesty King George V. on the 23d Feb., 1917. "Oriental" is meant to include African and Oceanic, for the studies to be encouraged are not confined to those connected with Asia but may almost be said to promise to become worldwide, so extensive is the field which they already cover, or which it is hoped they will ultimately deal with.

It has long been felt that we in England were wofully remiss in providing for the prosecution of such studies. The British Empire includes men of many different races and a vast diversity of tongues and variety of religions, manners and customs. To enable us to understand and sympathise with one another and so afford help and assistance to each other, it is above all necessary that opportunity should be afforded of learning one another's languages and way of thinking. In fact, in order that we may be able to accomplish the manifold tasks involved in bearing our share of "The White Man's Burden," it is necessary that we should diligently study all these matters. Hitherto no adequate opportunity has ever been given for doing this on a large scale. It is true that chairs of some of the leading oriental languages have long been established at the Universities of Oxford and Cambridge, and that some of the most distinguished Orientalists in the world have occupied these chairs from time to time; these have done good work, though on a very 
linited scale. The number of students of such languages as Arabic, Chinese, Persian, for example, to be found any year at Oxford or Cambridge was trifling. For this many causes were answerable. No proper encouragement was given to young men to devote themselves in earnest to these subjects. Those who did so were almost exclusively preparing for the Egyptian, or Indian, civil service, or perhaps for consular service in China. Few, if any, were studying with a view to missionary or commercial spheres of labour. The need of Oriental studies was not generally recognised. Even missionary societies rather discouraged than encouraged their students, if the latter desired to begin to lay a foundation at home for the languages they would imperatively require in the mission field. Moreover, it was impossible for many would-be students of Asian and African languages to go to these universities, even had adequate provision been there made for teaching all the languages and other subjects which they needed to know. The "Res angustae domi" had a good deal to do with the matter. A large number (and by no means the least industrious) of those who wished to study Eastern tongues were for a great part of their tirne engaged in commercial and other pursuits, not a few of them in London. Hence even the somewhat scanty provision for these Oriental studies made at Oxford and Cambridge was not fully appreciated.

Besides all this, it was self-evident that the capital of the empire was the natural place for the establishment of an Oriental Institution on a proper scale, at which the whole duty of the staff would be to encourage such studies to the greatest degree possible. The example of Petrograd, Paris, and Berlin (fas est et ab hoste doceri), and the great success of Oriental schools established there, made this clearer than ever. In the case of london* the desirability of establishing such an instilution was all the greater because London is the natural meeting-place of all nations, the veritable centre of the business (if not

*Lack of means had greatly hampered the proper development and the work of the Chairs of certain Oriental Languages estallished years ago at liniversity College and King's College, London. These have now been taken over (with the exception of the (hairs of Assyriology, Eyyptology, and Helorew) by the newly established institution. 
of the literary) world. In London, therefore at last a good beginning has been made with the School of Oriental Studies, which is comfortably and commodiously housed in Finsbury Circus.

In replying to the King's Speech when he declared the school open, on Feb. 23d last, Lord Curzon of Kedleston stated that the primary object of the institution was to become "an educational centre, where administrators and soldiers, merchant and missionary, will learn the languages, study the history, and absorb the customs of the East." He added that it was hoped "to send forth those men in every sphere better equipped for the work that they are about to undertake." Sir John Prescott Hewett, chairman of the governing body, said that what the school aimed at most of all was:

"First, to provide a place where our young men, who will presently be engaged in governing or garrisoning the Oriental and African parts of the empire, may learn the languages and study the literature, the religions, and the customs of the peoples with whom they will so soon be brought into contact, and their influence over whom will largely depend upon their familiarity with indigenous character, ideas, and institutions.

"Secondly, to offer a training to those who are about to proceed to the same countries to take part in commercial enterprise or other avocations, or for purposes of study and research.

"Thirdly, to furnish to the capital of the empire a meeting-ground and focus for scholars from the East of various nationalities, where, on their visits to this country, they may be assured of a sympathetic welcome, and find at hand, if they desire them, opportunities for study among those engaged in kindred pursuits."

In the words of the Charter, the scope of the institution's labours is very wide indeed. It is to be "A School of Oriental Studies in the University of London to give instruction in the languages of Eastern and African peoples, Ancient and Modern, and in the Literature, History, Religion and Customs of those peoples, especially with a view to the needs of persons about to proceed to the East 
or to Africa for the pursuit of study and research, commerce or a profession, and to do all or any of such other things as the governing body of the school consider conducive or incidental thereto, having regard to the provision for those purposes which already exists elsewhere, and in particular to the co-ordination of the work of the school with that of similar institutions both in this country and in our Eastern and African Dominions and with the work of the University of London and its other schools."

At the outset, arrangements were made to provide instruction in no less than twenty languages, divided into seven groups. These were:

Group I.: (Ancient India): Sanskrit and Pali.

Group II.: (The Near East): 1, Arabic, comprising

(a) Classical Arabic and (b) Colloquial Arabic (the dialects of Egypt, Baghdad, and Syria); 2, Persian; 3, Turkish.

Group III.: (Northern, Eastern and Western India): 1, Hindustani and Hindi; 2, Bengali; 3, Marathi; 4, Gujarati.

Group IV.: (Southern India): 1, Tamil and Telugu; 2, Tamil and Singhalese.

Group V.: (Further India, Malay Archipelago): 1, Burmese; 2, Malay.

Group VI.: (The Far East): 1, Chinese; (a) Mandarin;

(b) Cantonese; 2, Japanese; 3, Tibetan.

Group VII.: (African Languages): 1, Swahili and Bantu Languages; 2, Hausa.

In addition to these the governing body in its preliminary announcement expressed the hope that-later on-it would be possible to add to the curriculum the following languages: Amharic, Armenian, Assamese, Luganda, Melanesian Languages, Panjabi, Pashto, Polynesian Languages, Siamese, Somali, Yoruba, and Zulu.

Were the course of studies confined to languages alone, no one could say that the scheme was lacking in ambition. But we shall see further on that much more than merely linguistic work is aimed at. Under the able directorship of Sir E. Denison Ross it is not too much to say that the 
Institution, although so young, is already in a fair way to the attainment of the important objects for which it has been started. There were some 75 students on the books during the first term, while at the beginning of the second term al.out 100 entered.

It is well understood that the languages taught must be studied both theoretically and practically. For instance, it will be noticed that in Arabic instruction is not confined to the "Book Arabic," the classical tongue, but that the modern spiken dialects of Egypt, Syria, and Mesopotamia, are also carcfully taught.

In studying a foreign tongue there are ccrtain dangers to be arrided. On the one hand, if the teacher is an Finglishman, while he may have a thoroughly scientific knowledge of tlae language which he is teaching, his prouuncialion may be by no means perfect. He may also have a tendency to use stilted and somewhat antiquated phraseology. On the other hand, he should have the groat advantnge "ver a "native" teacher of knowing by personal experience the special difficulties of whatever kiud which the language presents to a European st ident, and what are the hest means of overcoming them. Again, if the instructur is an Asiatic or an African who is teaching liis own mother-tongue, his knowlerge of it, in both its ancicnl and ils molern form, ought to be all that can be Ileircel. and in pronunciation and acquaintance with all 114. vilislly impurlant ninutiae of the illiom he should be superior to the English teacher. Yet he may have no idea whalever of low to teach the language to Europeans, unless under carcful direction. Now the method which would coinhise the advantages and eliminate the disadvantages of having either a European or a "native" teacher would be to have both, working in perfect harmony with one another. Alas! this ideal state of things is rarcly attainable, least of all in the mission field (except in a few places where schools of languages have bcen establisher at (certain great centres). But it is attained at the I,ondon Sclinol of Oriental Studies, as a glance at the list of lecturers and assistant lecturers will show. Native teachers of the colloquial dialects of such tongues 
as Arabic, Chinese, Persian, etc., give instruction, under the direction of European lecturers.

As we have intimated above, besides a large number of languages, instruction is given in many other subjects. One of the most important of these is phonetics, on which a course of six lectures has been arranged to be delivered during the summer term this year. Other courses are given on such subjects as Oriental Religions and Philosophies, African Religions, Eastern Family Life, Customs, Essential Ideas, Indian Law and History, and so on. Students who wish to learn any language not already on the list (provided it be an Oriental language) are encouraged to apply to the director. Doubtless Sir E. Denison Ross would similarly give favourable consideration to any reasonable suggestion with regard to courses of lectures on subjects other than linguistic.

From what has been said it must be evident what an inestimable boon the establishment of this School of Oriental Studies is to all who desire to devote themselves to foreign mission work. The school is most valuable to all who are at all connected with Asia and Africa or interested therein; but it would be impossible to exaggerate its value to all missionary students and societies. In one of the publications of the new Institution it is styled "A Pillar of Empire and Commerce." Deserving as it doubtless is of such a title, it might with far more justice be termed a "Royal Highway to Mission Work." The key is thus put into the young missionary's hand wherewith to open many of the doors through which he must pass to do his Master's work. Moreover, the institution desires to encourage missionary students to avail themselves of its advantages. In a letter to the writer the director says, "We have a fair number of missionary students studying such languages as Persian, Tibetan and Hindustani, and we are in close touch with such organisations as the Board of Study for the Preparation of Missionaries, the Moravian Missions, and the Zenana Bible and Medical Mission; and I hope we shall have many missionary students in the future." 
There can be no question that all missions should make the fullest possible use of this language school. It may sometimes be of value to missionaries home on furlough, but to those going out for the first time it will soon be proved to be indispensable. Instead of any longer depending on the rather haphazard methods of learning languages adopted until very recently in the mission field, missionaries designate can now obtain at home, under the most favourable auspices, a thorough grounding in the tongues spoken in their future spheres of work. The only difficulty still remaining is to impress this fact on the minds of the governing bodies of the various missionary societies, and persuade them to fix the locations of their outgoing missionaries a year beforehand, thus enabling them to begin their linguistic training before leaving England. The Indian civil service, the chamber of commerce, the army, the diplomatic service,-all admit the necessity of such preliminary study. It is to be hoped that our great missionary societies will imitate them, now that the way is open for their candidates to obtain careful and most valuable instruction at a very slight expense. Health, time, and money will thus all alike be saved, nor will it henceforth be possible for a man or woman to go out to the foreign field and be compelled to return home in a year or two through inability to learn a language. This "inability,"-if such a thing really exists—will be detected in the School of Oriental Studies and probably removed by the care and advice of the professors and lecturers of the school. If not so removed, its detection at an early stage will prevent disappointment and waste of time.

We think so highly of the School and its wide possibilities that we again express our confident hope that missionaries will fully avail themselves of them. It would have been well worth while for missionary societies to combine years ago to start and support such a school at their own expense for training their missionaries, had not a very shortsighted policy prevented such a step. Now, however, that the institution has been founded and has successfully begun its work under the auspices of the 
state, and on a far larger and more effective scale than would have been otherwise possible, all who are interested in the spread of Christ's Kingdom should thank God for the greatest boon conferred upon workers in the mission field in this generation. It comes just at the very time when we feel that new fields will be opened as a result of the present war, and when a vastly increased number of missionaries will be required to enter upon them.

W. St. Clair Tisdalu.

St. George's Vicarage, Deal, England. 